\title{
Relationship between Human Disturbance and Habitat Use by the Endangered François' Langur (Trachypithecus francoisi) in Mayanghe Nature Reserve, China
}

\author{
Jialiang Han ${ }^{1}$, Guohou Liu ${ }^{1 *}$, Wenke Bai ${ }^{2,3}$, Qixian Zou ${ }^{4}$, Ye Cao ${ }^{5}$, Caiquan Zhou ${ }^{2,3 *}$ \\ and Guy Michael Williams ${ }^{6}$ \\ ${ }^{1}$ College of Grassland Resources and Environment, Inner Mongolia Agricultural \\ University, Hohhot, China \\ ${ }^{2}$ Key Laboratory of Southwest China Wildlife Resources Conservation, China West \\ Normal University, Nanchong, China. \\ ${ }^{3}$ Institute of Ecology, China West Normal University, Nanchong, China \\ ${ }^{4}$ Mayanghe National Nature Reserve Administration, Tongren, China \\ ${ }^{5}$ Ningxia Hui Autonomous Region Forestry Investigation and Planning Institute, \\ Yinchuan, China \\ ${ }^{6}$ The Biodiversity Consultancy, 3E King's Parade, Cambridge. CB2 1SJ, United \\ Kingdom
}

\section{A B S T R A C T}

François' langur (Trachypithecus francoisi) is an endangered primate that has experienced a decline in population size and associated loss in habitat as a result of human disturbance (IUCN, 2020). We investigated human disturbance and habitat use of François' langur in Mayanghe Nature Reserve, Guizhou, China, by analyzing the effects of various types of human disturbance on habitat use using the spatial simultaneous autoregressive error model (SAR). We found that habitat use intensity of François' langur was positively correlated with slope and distance to roads but was negatively correlated with elevation and distance to bee-keeping locations and grazing locations. The effects of each different human disturbance type were consistently correlated with one another, except for distance to bee-keeping locations and grazing locations. Our results indicate that langurs are restricted to small areas along the rivers in Mayanghe Nature Reserve and area also used by small local roads. The ecological effect of the edge of a road "road-effect zone" was estimated to be $1400 \mathrm{~m}$, shorter than the maximum daily travel distance of the François' langur. Therefore, we suggest that an important conservation intervention for supporting the persistence of the species should involve controlling the expansion of road construction to minimize the impacts of human disturbances on the langurs.

\begin{tabular}{|c|}
\hline Article Information \\
\hline Received 04 July 2020 \\
\hline Revised 04 September 2020 \\
\hline Accepted 24 September 2020 \\
\hline $\begin{array}{l}\text { Available online } 26 \text { January } 2021 \\
\text { (early access) }\end{array}$ \\
\hline Published 20 November 2021 \\
\hline Authors' Contribution \\
\hline $\begin{array}{l}\text { GL, JH, CZ and QZ conceived the } \\
\text { project, which was led by GL, JH } \\
\text { and } C Z \text {. JH, WB, YC conducted the } \\
\text { analysis. JH wrote the manuscript, } \\
\text { with contributions from MW. }\end{array}$ \\
\hline Key words \\
\hline $\begin{array}{l}\text { François' langur, Human } \\
\text { disturbances, Habitat use, Spatial } \\
\text { simultaneous autoregressive error } \\
\text { models, Road-effect, Mayanghe nature } \\
\text { reserve }\end{array}$ \\
\hline
\end{tabular}

\section{INTRODUCTION}

$\mathrm{F}$ rançois' langur (Trachypithecus francoisi) (the langur) is an endangered colobine species, distributed from its southern extent at the Red River in Vietnam, across the Chinese border as far north as the Daming Hills in Guangxi and Xingyi in Guizhou (Brandon-Jones, 2002). It is estimated that François' langur has a global population of about 2,000 individuals (Zeng et al., 2013). In China, the distribution of the langur was largely restricted to areas characterized by karst topography at elevations of

\footnotetext{
* Corresponding author: guohouliu@163.com, drcqzhou1@163.com 0030-9923/2022/0001-0191 \$ 9.00/0

Copyright 2022 Zoological Society of Pakistan
}

$120 \sim 1,400 \mathrm{~m}$ in Guangxi, Guizhou and Chongqing (Ma, 1988; Ma et al., 1989; Li, 1993; Li et al., 2007). Due to habitat destruction, habitat fragmentation, and poaching, François' langur is locally extinct in Fangchen, Jingxi, Leye, Longzhou, Shanglin, and Tian'e county, Guangxi province (Li et al., 2007). François' langur is listed as endangered on the International Union for Conservation of Nature Red List (IUCN, 2020) and is considered a firstgrade protected species of wildlife in China (Li et al., 2010; Wang et al., 2011; Niu et al., 2016).

Human activities threaten the long-term survival of many primate species, primarily through habitat loss and fragmentation (Guisan and Thuiller, 2005; Ashcroft et al., 2011; Chang et al., 2012) roads and railways alter habitats and reduce the interconnectedness of forest landscapes, resulting in habitat loss and fragmentation (Clauzel et al., 
2013, 2015). This lack of connectedness reduces genetic exchange among populations (Way, 1977; Andrews, 1990; Carr et al., 2002; Zhu et al., 2010), causing population decline and decrease in genetic diversity (Chang et al., 2012). Hunting may also have a significant impact on local population size (Huang et al., 2002; Hu et al., 2004), whilst logging and cultivation of domestic crops may further increase fragmentation and loss of forest habitats (Van Dyke et al., 1986; Huang et al., 2002).

To better understand how human disturbance has affected the langur and to help conservation managers design more effective protection plans, we investigated the relationship between distance to various agents of human disturbance, and habitat use intensity by François' langur in Mayanghe Nature Reserve, China.

\section{MATERIALS AND METHODS}

\section{Study area}

The study area encompasses the Mayanghe Nature Reserve, located in Guizhou, on the border of Yanhe and Wuchuan Counties (Fig. 1). The total area of the reserve is $311.13 \mathrm{~km}^{2}$, with a core area of $105.43 \mathrm{~km}^{2}$. This reserve has typical karst geophysical features (Karst, terrain usually characterized by barren, rocky ground, caves, sinkholes, underground rivers, and the absence of surface streams and lakes. It results from the excavating effects of underground water on massive soluble limestone.) and occupies an altitude ranging from $280 \mathrm{~m}$ to $1441 \mathrm{~m}$ above sea level; with a mean annual temperature of $18.3^{\circ} \mathrm{C}$, and a mean annual precipitation of $1139 \mathrm{~mm}$ (Chen, 2001). Forests cover about $64 \%$ of the total area of the reserve, including evergreen broadleaved forest, mixed evergreen deciduous broadleaved forest, and mixed conifer-broadleaved forests (Chen, 2001). As the known range of François' langur is concentrated along Mayanghe River and Hongduhe River of the reserve (Wang et al., 2011; Zeng et al., 2013; Niu et al., 2016), the study area was initially defined by these two rivers, which also contains the most common human disturbance in the greater study area (including farmland, grazing location, road, households, and bee-keeping locations).

\section{Data collection and variable calculations}

The period of the survey for recording both François' langur and the human disturbance activities in the Mayanghe Nature Reserve covered the period from October 2017 to August 2018, carried out over the area defined by $28^{\circ} 37^{\prime} 30^{\prime \prime}-28^{\circ} 54^{\prime} 20^{\prime \prime} \mathrm{N}$ and 108 $3^{\prime} 58^{\prime \prime}-108^{\circ} 19^{\prime} 45^{\prime \prime} \mathrm{E}$. Langur presence was determined via a variety of direct and indirect recordings (e.g., feces, evidence of feeding, sleeping sites, direct observations, and anecdotal records from the reserve manager). In total during the survey period 229 locations were recorded with signs of langur. Based on the presence data, a density map for the langur was generated by using the kernel density analysis in ArcGIS v10.5 (ESRI, Redlands, USA), which was used to demonstrate the intensity of langur activity and habitat use in the study area. In addition, the location of human activities were recorded, including 30 bee-keeping sites, 16 grazing sites, 6 townships and 3 power stations each recorded using a global positioning system (GPS). The location of all roads, households and farmland was obtained from government maps and Google Earth (Google Inc., Mountain View, USA; Fig. 2). Based on these data, seven human disturbance variables were included in ArcGIS including distance from each langur location to the nearest road (roads included in this study were either county road or back roads), households, townships, farmland, grazing area, or bee-keeping area. For those sites where the langur was found to be present, three topographic variables were recorded including elevation, slope, and aspect.

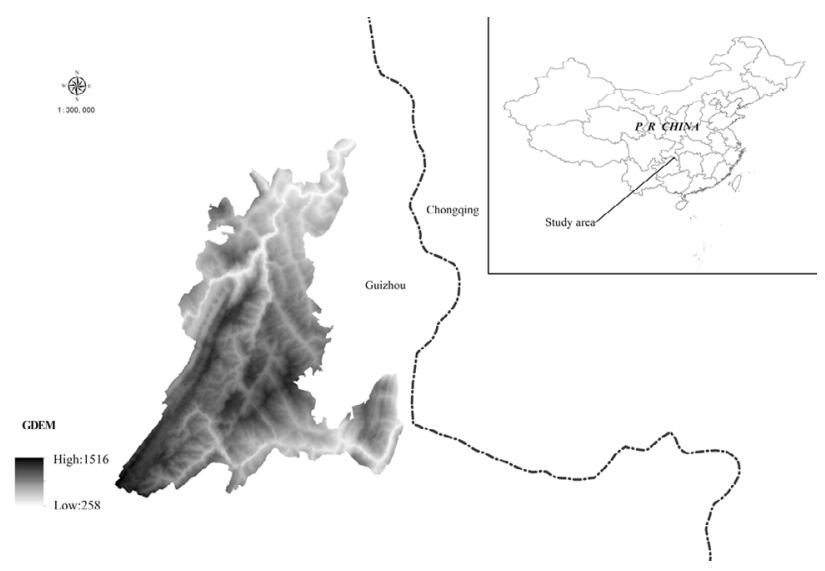

Fig. 1. Mayanghe Nature Reserve, established to protect the François' langur in Guizhou, provinces, China.

Finally, ten additional environmental variables were obtained (Table I) and the Pearson's correlation coefficient was applied to test the multicollinearities among these ten variables, some of which were subsequently excluded from the analysis (Hosmer and Lemeshow, 2000). The environmental variables with correlation values less than $| \pm 0.7|$ were retained. All the variables except the distance to the nearest edge of residence area were included in the following analysis (Table II).

\section{Statistical analysis}

Spatial simultaneous autoregressive error models (SAR) were used to investigate the relative effect of human disturbance variables and topographic variables on the 
Table I. Definition and description of habitat variables in Mayanghe National Nature Reserve, China.

\begin{tabular}{lll}
\hline Class & Variable & Description \\
\hline $\begin{array}{l}\text { Topographic } \\
\text { variable }\end{array}$ & Elevation (ELE) & Elevation of the location above sea level \\
& Slope (SLO) & Degree of the slope at the locations ranging from $0^{\circ}$ to $90^{\circ}$ \\
& Aspect (SLA) & Aspect of the slope at the locations ranging from $0^{\circ}$ to $360^{\circ}$ \\
Human disturbance & Distance to households (DHO) & Distance from the locations to the nearest edge of the residence area \\
& Distance to road (DRO) & Distance from the locations to the nearest road \\
Distance to farmland (DFA) & Distance from the locations to the nearest edge of the farmland \\
& Distance to bee-keeping location (DBK) & Distance from the locations to the nearest bee keeping site \\
& Distance to grazing location (DGR) & Distance from the locations to the nearest grazing site \\
& Distance to power station (DPO) & Distance from the locations to the nearest power station \\
& Distance to township (DTO) & Distance from the locations to the nearest township
\end{tabular}

Table II. The values (right-upper triangle) and corresponding significance (left-lower triangle) of pearson correlation coefficients between the ten selected variables.

\begin{tabular}{|c|c|c|c|c|c|c|c|c|c|}
\hline & $\begin{array}{l}\text { Eleva- } \\
\text { tion }\end{array}$ & Aspect & Slope & $\begin{array}{l}\text { Distance } \\
\text { to road }\end{array}$ & $\begin{array}{l}\text { Distance to } \\
\text { power station }\end{array}$ & $\begin{array}{l}\text { Distance to } \\
\text { farmland }\end{array}$ & $\begin{array}{l}\text { Distance to } \\
\text { bee-keeping }\end{array}$ & $\begin{array}{l}\text { Distance to } \\
\text { grazing location }\end{array}$ & $\begin{array}{l}\text { Distance to } \\
\text { township }\end{array}$ \\
\hline Elevation & & 0.074 & 0.016 & 0.248 & 0.54 & 0.27 & -0.399 & -0.497 & 0.301 \\
\hline Aspect & ns & & 0.139 & -0.051 & 0.018 & -0.035 & -0.007 & -0.047 & 0.082 \\
\hline Slope & ns & $*$ & & 0.194 & -0.087 & 0.134 & -0.106 & -0.098 & 0.305 \\
\hline Distance to road & $* * *$ & $\mathrm{~ns}$ & $* *$ & & 0.234 & 0.634 & -0.147 & -0.365 & 0.634 \\
\hline $\begin{array}{l}\text { Distance to } \\
\text { power station }\end{array}$ & $* * *$ & ns & ns & $* * *$ & & 0.334 & -0.329 & -0.346 & -0.093 \\
\hline $\begin{array}{l}\text { Distance to } \\
\text { farmland }\end{array}$ & $* * *$ & ns & * & $* * *$ & $* * *$ & & -0.301 & -0.324 & 0.279 \\
\hline $\begin{array}{l}\text { Distance to } \\
\text { bee-keeping } \\
\text { location }\end{array}$ & $* * *$ & ns & ns & $*$ & $* * *$ & $* * *$ & & 0.47 & -0.319 \\
\hline $\begin{array}{l}\text { Distance to } \\
\text { grazing location }\end{array}$ & $* * *$ & ns & ns & $* * *$ & $* * *$ & $* * *$ & $* * *$ & & -0.352 \\
\hline $\begin{array}{l}\text { Distance to } \\
\text { township }\end{array}$ & $* * *$ & ns & $* * *$ & $* * *$ & $\mathrm{~ns}$ & $* * *$ & $* * *$ & $* * *$ & \\
\hline
\end{tabular}

habitat use of the langur. To address the study question, four SAR models were run based on different combinations of predictor variables. The combinations were: 1) a model only including intercept, 2) a model including all the topographic variables, 3) a model including all the human disturbance variables and 4) a full model including all the variables. The Akaike information criterion (AIC) was used for model selection, and the lowest AIC score and highest Akaike weights were used to select the most parsimonious best-fit models (Anderson, 2008).

The purpose of the test was to determine whether the intensity of habitat use increased as distance from human disturbance increased. We used a liner model, polynomial model, and logarithmic model to visualize the relationship between distance from human disturbance and habitat use intensity. We divided the study region into $300 \mathrm{~m}^{2}$ patches and established transects in each square such that the survey sites were distributed uniformly throughout the study area. We calculated habitat use intensity in region $i$ of width $300\left(\mathrm{GHI}_{\mathrm{i}}{ }^{300}\right)$ as $\mathrm{N}_{\mathrm{i}} / \mathrm{A}_{\mathrm{i}}$, where $\mathrm{N}_{\mathrm{i}}$ is the number of signs of François' langur in region $\mathrm{i}\left(\mathrm{m}^{2}\right), \mathrm{A}_{\mathrm{i}}$ was the area of region $\mathrm{i}\left(\mathrm{m}^{2}\right)$. 


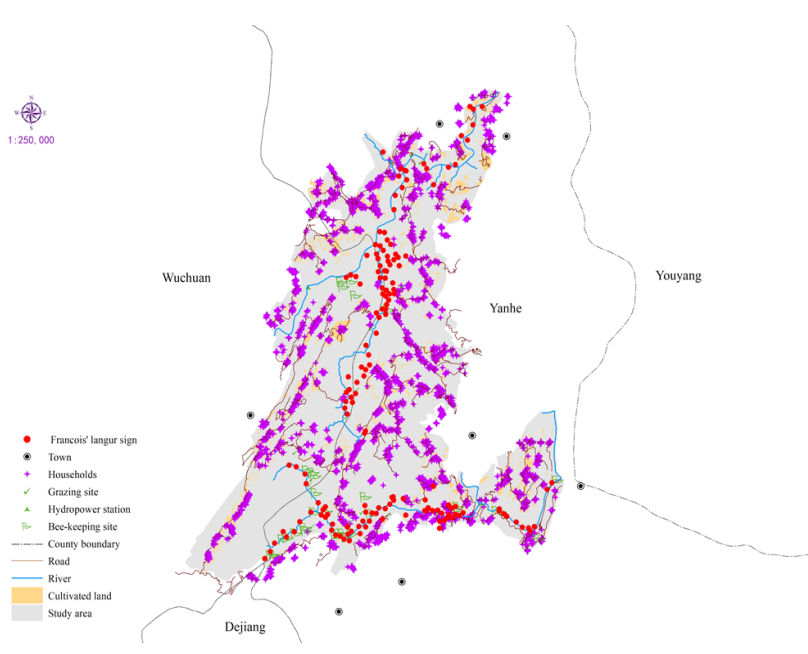

Fig. 2. The locations of François' langur signs and human disturbance in the study area.

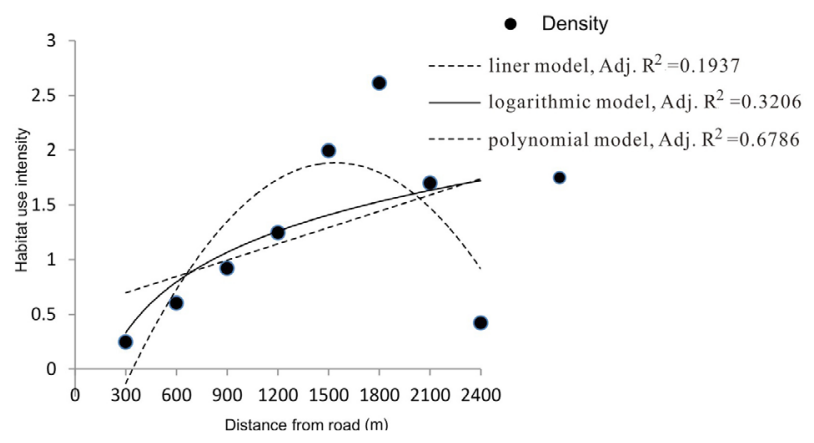

Fig. 3. Line- and curve-fitting analysis of the relationship between the François' langur habitat use intensity and distance to households.

\section{RESULTS}

\section{SAR models}

According to the SAR models, the full model including all the variables outperformed the remaining three models, with the lowest AICc value of 699.999 . The results indicated that both topographic and human disturbance factors were important in determining habitat use by the langur (Table III). However, only four of the nine variables in the full model have a significant effect on habitat use of François' langur (Table IV). Specifically, distance from the observation locations to the nearest road and the slope of the location both have positive effect on the activity intensity of the langur, with influence coefficients of 0.415 and 0.153 respectively. Conversely, distance from the observation locations to the nearest beehive and distance from the locations to the nearest grazing location both have negative effect on the activity intensity of the langur, with influence coefficients of -0.632 and -0.483 respectively.

Table III. Model comparsion for the four spatial simultaneous autoregressive error models (SAR) based on different combinations of predictor variables. The best model with the lowest AICc was highlighted in bold. df: number of parameters; AICc: Akaike's Information Criterion for finite sample size; $\triangle \mathrm{AICc}$ difference of AICc from the lowest AICc; wAIC: model weight.

\begin{tabular}{llllll}
\hline Model & df & log likelihood & AICc & $\Delta$ AIC & wAIC \\
\hline Null & 3 & -370.657 & 747.314 & 47.315 & $<0.001$ \\
TOP & 6 & -363.217 & 738.434 & 38.435 & $<0.001$ \\
HD & 9 & -354.353 & 726.706 & 26.707 & $<0.001$ \\
Full & 12 & -337.999 & 699.999 & 0 & 0.999 \\
\hline
\end{tabular}

Table IV. The output of spatial simultaneous autoregressive error models (SAR) that included all the variables.

\begin{tabular}{lllll}
\hline & $\begin{array}{l}\text { Esti- } \\
\text { mate }\end{array}$ & $\begin{array}{l}\text { Std. } \\
\text { error }\end{array}$ & $\mathbf{z}$ & $\operatorname{Pr}(>|\mathbf{z}|)$ \\
& 0.415 & 0.173 & 2.396 & $0.017^{*}$ \\
\hline Distance to road & 0.173 & 0.172 & 1.004 & 0.315 \\
Distance to power station & 0.14 & 0.121 & -1.158 & 0.247 \\
$\begin{array}{l}\text { Distance to farmland } \\
\text { Distance to bee-keeping }\end{array}$ & -0.632 & 0.172 & -3.667 & $<0.001^{* * *}$ \\
location & & & & \\
Distance to grazing & -0.483 & 0.152 & -3.178 & $<0.001^{* * *}$ \\
location & & & & \\
Distance to township & -0.005 & 0.193 & -0.025 & 0.980 \\
Alope & 0.153 & 0.068 & 2.266 & $0.023^{*}$ \\
Elevation & -0.609 & 0.109 & -5.596 & $<0.001^{* * *}$ \\
Aspect & -0.102 & 0.063 & -1.625 & 0.104 \\
\hline
\end{tabular}

\section{Human disturbance effect zones}

Line and curve-fitting was used to analyze each of the human disturbances, with the results indicating that only distance to roads had a strong fit with habitat use intensity. In addition, the polynomial model was a better fit for distance to road (Fig. 3), compared to the linear model or the logarithmic model $\left(\mathrm{R}^{2}>0.6\right)$. The polynomial model showed a significant increase in habitat use intensity at distance $<1,400 \mathrm{~m}$ to road. 


\section{DISCUSSION}

Our results suggest that seven human disturbance and three topographic variables define the best-fit model (composed of 10 variables). It indicated that both human disturbance and topographic variables had substantial effects on the langur activity. As many previous studies have shown, both habitat and human disturbance predict wildlife abundance and distribution (Morrison, 2001; Bhattarai and Kindlmann, 2013). The habitat selection processes and the habitat requirements of the langur have been studied thoroughly (Zhou et al., 2010, 2011, 2018; Hu, 2011; Zeng et al., 2013), as have the relationships between the langur and local human attitudes and perceptions (Niu et al., 2019).

The impact of roads on wildlife distribution, abundance, and population interconnectedness has also been well studied (Andrews, 1990; Carr et al., 2002; Anderson and Raza, 2010; Clauzel et al., 2015). However, most previous studies have assessed the impact of linear infrastructure on wild animals, and typically show that distribution decreases as road density increases (Eigenbrod et al., 2009; Clauzel et al., 2013, 2015). Roads likely act as barrier to wildlife movements (Forman and Deblinger, 2000; Trombulak and Frissell, 2000; Coffin, 2007; Zhu et al., 2011). Thus, roads might have substantial (negative) impact on the langur activity and distribution. In the bestfit model identified in this study, distance from roads was positively correlated with the intensity of langur activity. The length of back roads in the greater study locality has increased rapidly over the past 10 years. The study area includes a small stretch of county road along the Mayanghe River. Local residents frequently report spotting François' langurs either crossing this road or foraging nearby. This indicates that the langur have become accustomed to the road in these areas, despite the danger the road presents. However, the most preferred areas inhabited by François' langur were far from the road, as areas near the road tend to be occupied by buildings e.g. households and farms, with intense human activity, and contribute to fragmenting the langurs habitat landscape. Thus, François' langur typically avoided these areas.

Several studies have focused on the impact of farmland on wildlife habitat selection (Schmitt and Seitz, 2002; Rodriguez and Delibes, 2003; Li et al., 2007; Zhou et al., 2010, 2018; Huang et al., 2017) as many wild animals avoid such agricultural areas (Liu et al., 1999). In the bestfit model in our study, the intensity of langur activity was not significantly correlated with distance to cultivated land. As the slope of the areas of cultivated land was gentle, this area was suitable for cultivation, but was not as suitable for François' langur, as sleeping sites and food resources were insufficient. Therefore, the langur typically avoided these areas, although we found that the langur did forage in farmland, for feed including corn, sweet potatoes, and other crops, especially in summer. This finding was consistent with previous studies (Hu, 2011; Wang et al., 2011; Zeng et al., 2013: Niu et al., 2016).

The study suggests that habitat use intensity was generally higher when langur locations were closer to both bee-keeping locations and grazing locations. For other animals, livestock grazing is often a significant human disturbance (Zhang et al., 2007, 2017; Hull et al., 2011) Grazing locations are often far from cultivated land and residential buildings, and the slope of locations tends to be steep, with less human disturbance. As a result, these grazing areas are suitable for the langur. In the study area, human inhabitants placed bee barrels at the bottom or the middle of cliffs, so as to protect the barrels from the rain. The sleeping site of the langur was often observed on top of bee barrels. Thus both grazing and beekeeping can be considered as non-fixed disturbances, and may have limited effect on langur distribution.

It has been shown that animals may tolerate human disturbances at a certain distance (Huggett, 2005; Luck, 2005; Groffman et al., 2006; Zhao et al., 2017). Here, the relationship between the intensity of langur activity and the distance to roads was represented by a polynomial regression. Although it was difficult to determine the inflection points, we can use these regression curves to provide a model that suitably illustrates the effect of road on the intensity of langur habitat use. From this study the effect zone of road was estimated as being $1400 \mathrm{~m}$, shorter than the maximum daily travel distance of the François' langur (Hu et al., 2018). Although many previous studies have investigated the relationship between distance to human disturbance and François' langur distribution, our study is the first to define the size of the zone within which François' langur habitat use is affected by human disturbances.

\section{CONCLUSION}

Many humans live within the study area and within the boundaries of the Mayanghe Nature Reserve, with thousands of households and large areas of farmland distributed around or embedded within the François' langur range. The langur is thus restricted to a limited area within the Mayanghe Nature Reserve. Our study focused on how the type of disturbance and its distance to the langurs, affected François' langur distribution. It is our recommendation that protected area management institutions should strictly control both road and household construction, in order to reduce the impact on 
the endangered langur. Our findings may provide useful data for management institutions attempting to improve François' langur conservation and guide areas of focus for further prioritization of conservation interventions.

\section{ACKNOWLEDGMENT}

We are grateful to our field assistants Yong Li. We would like to thank Mayanghe Nature Reserve Bureau for their assistance for data collection.

\section{Conflict of interest}

The authors have declared no conflict of interest.

\section{REFERENCES}

Anderson, D.R., 2008. Model based inference in the life sciences. A premer on evidence. Springer, New York, USA. https://doi.org/10.1007/978-0-38774075-1

Anderson, R.P. and Raza, A., 2010. The effect of the extent of the study region on GIS models of species geographic distributions and estimates of niche evolution: preliminary tests with montane rodents (genus Nephelomys) in Venezuela. J. Biogeogr., 37: 1378-1393. https://doi.org/10.1111/j.13652699.2010.02290.x

Andrews, A., 1990. Fragmentation of habitat by roads and utility corridors: A review. Austral. Zool., 26: 130-141. https://doi.org/10.7882/AZ.1990.005

Ashcroft, M.B., French, K.O. and Chisholm, L.A., 2011. An evaluation of environmental factors affecting species distributions. Ecol. Model., 222: 524-531. https://doi.org/10.1016/j.ecolmodel.2010.10.003

Bhattarai, B.P. and Kindlmann, P., 2013. Effect of human disturbance on the prey of tiger in the Chitwan National Park - Implications for park management. J. Environ. Manage., 131: 343-350. http://doi.org/10.1016/j.jenvman.2013.10.005

Brandon-Jones, D., 2002. Book review: Primate taxonomy. Colin groves, smithsonian institution press, Washington, District of Columbia, 2001, viii+ 350 pp., US $\$ 65.00$ (hardback). Int. J. Primatol., 23: 1352-1355.

Carr, L.W., Fahrig, L. and Pope, S.E., 2002. Impacts of landscape transformation by roads. Apply. Lands. Ecol. boil. conserve., Springer, pp. 225-243. https:// doi.org/10.1007/978-1-4613-0059-5 13

Chang, Z.F., Luo, M.F., Liu, Z.J., Yang, J.Y., Xiang, Z.F., Li, M. and Vigilant, L., 2012. Human influence on the population decline and loss of genetic diversity in a small and isolated population of Sichuan snub-nosed monkeys (Rhinopithecus roxellana). Genetica, 140: 105-114. https://doi.org/10.1007/ s10709-012-9662-9

Chen, Z., 2001. A preliminary study on home range of Francois's langur. Guizhou For. Sci. Technol., 29: 34-37.

Clauzel, C., Girardet, X. and Foltête, J-C., 2013. Impact assessment of a high-speed railway line on species distribution: Application to the European tree frog (Hyla arborea) in Franche-Comté. J. Environ. Manage., 127: 125-134. https://doi.org/10.1016/j. jenvman.2013.04.018

Clauzel, C., Xiqing, D., Gongsheng, W., Giraudoux, P. and Li, L., 2015. Assessing the impact of road developments on connectivity across multiple scales: Application to Yunnan snub-nosed monkey conservation. Biol. Conserv., 192: 207-217. https:// doi.org/10.1016/j.biocon.2015.09.029

Coffin, A.W., 2007. From roadkill to road ecology: A review of the ecological effects of roads. J. Transp. Geog., 15: 396-406. https://doi.org/10.1016/j. jtrangeo.2006.11.006

Eigenbrod, F., Hecnar, S.J. and Fahrig, L., 2009. Quantifying the road-effect zone: threshold effects of a motorway on anuran populations in Ontario, Canada. Ecol. Soc., pp. 14. https://doi.org/10.5751/ ES-02691-140124

Forman, R.T. and Deblinger, R.D., 2000. The ecological road-effect zone of a Massachusetts (USA) suburban highway. Conserv. Boil., 14: 36-46. https://doi.org/10.1046/j.1523-1739.2000.99088.x

Groffman, P.M., Baron, J.S., Blett, T., Gold, A.J., Goodman, I., Gunderson, L.H., Levinson, B.M., Palmer, M.A., Paerl, H.W. and Peterson, G.D., 2006. Ecological thresholds: the key to successful environmental management or an important concept with no practical application? Ecosystems, 9: 1-13. https://doi.org/10.1007/s10021-003-0142-z

Guisan, A. and Thuiller, W., 2005. Predicting species distribution: offering more than simple habitat models. Ecol. Lett., 8: 993-1009. https://doi. org/10.1111/j.1461-0248.2005.00792.x

Hosmer, D.W. and Lemeshow, S., 2000. Applied logistic regression.2nd edition. New York: John Wiley and Sons. pp. 373. https://doi.org/10.1002/0471722146

$\mathrm{Hu}, \mathrm{G} ., 2011$. Dietary breadth and resource use of François' langur in a seasonal and disturbed habitat. Am. J. Primatol., 73: 1176-1187. https:// doi.org/10.1002/ajp.20985

Hu, G., Dong, X., Wei, Y., Zhu, Y. and Duan, X., 2004. Evidence for a decline of François' langur Trachypithecus francoisi in Fusui Nature Reserve, 
south-west Guangxi, China. Oryx, 38:48-54. https://doi.org/10.1017/S0030605304000080

Hu, G., Dong, X., Zhou, Caiquan and Wei, Y., 2018. Black phantoms the François' langur, their ecology and behavior in southwest chain. Beijing. China.

Huang, C. and Li, Y., 2005. How does the whiteheaded langur (Trachypithecus leucocephalus) adapt locomotor behavior to its unique limestone hill habitat? Primates, 46: 261-267. https://doi. org/10.1007/s10329-005-0130-3

Huang, C., Wei, F., Li, M., Quan, G. and Li, H., 2002. Current status and conservation of whiteheaded langur (Trachypithecus leucocephalus) in China. Biol. Conserv., 104: 221-225. https://doi. org/10.1016/S0006-3207(01)00168-9

Huang, Z., Yuan, P., Huang, H., Tang, X., Xu, W., Huang, C., and Zhou, Q., 2017. Effect of habitat fragmentation on ranging behavior of white-headed langurs in limestone forests in Southwest China. Primates, 58: 423-434. https://doi.org/10.1007/ s10329-017-0600-4

Huggett,A.J., 2005. The concept and utility of 'ecological thresholds' in biodiversity conservation. Biol. Conserv., 124: 301-310. https://doi.org/10.1016/j. biocon.2005.01.037

Hull, V., Xu, W., Liu, W., Zhou, S., Viña, A., Zhang, J., Tuanmu, M-N., Huang, J., Linderman, M. and Chen, X., 2011. Evaluating the efficacy of zoning designations for protected area management. Biol. Conserv., 144: 3028-3037. https://doi. org/10.1016/j.biocon.2011.09.007

IUCN, 2020. The IUCN red list of threatened species. Version 2020-1. https://www.iucnredlist.org. Downloaded on 19 March 2020.

Li, W., Guo, A., Wang, B., Wu, A., Liu, N. and Hu, G., 2010. Nutritional contents of winter food and its influences on food choice of Francois' langur at Mayanghe Nature Reserve. Acta Theriol. Sin., 30: 151-156.

Li, Y., Huang, C., Ding, P., Tang, Z. and Wood, C., 2007. Dramatic decline of François' langur Trachypithecus francoisi in Guangxi province, China. Oryx, 41: 38-43. https://doi.org/10.1017/ S0030605307001500

Li, Z-Y., 1993. Preliminary investigation of the habitats of Presbytis francoisi and Presbytis leucocephalus, with notes on the activity pattern of Presbytis leucocephalus. Folia Primatol., 60: 83-93. https:// doi.org/10.1159/000156678

Liu, J., Ouyang, Z., Taylor, W.W., Groop, R., Tan, Y. and Zhang, H., 1999. A framework for evaluating the effects of human factors on wildlife habitat: the case of giant pandas. Conserv. Boil., 13: 1360-1370. https://doi.org/10.1046/j.1523-1739.1999.98418.x

Luck, G., 2005. An introduction to ecological thresholds. Biol. Conserv., 124: 299-300. https:// doi.org/10.1016/j.biocon.2005.01.042

Ma, S., 1988. The recent distribution, status and conservation of primates in China. Acta Theriol. Sin., 8: 250-260.

Ma, S., Wang, Y. and Poirier, F.E., 1989. Taxonomy and distribution of the Francois' langur (Presbytis francoisi). Primates, 30: 233-240. https://doi. org/10.1007/BF02381308

Morrison, M.L., 2001. A proposed research emphasis to overcome the limits of wildlife-habitat relationship studies. J. Wildl. Manage., 65: 613-623. http://doi. org/doi:10.2307/3803012

Niu, K., Liu, W., Xiao, Z., Wu, A., Yang, T., Riondato, I., Ellwanger, A.L., Ang, A., Gamba, M. and Yang, Y., 2019. Exploring local perceptions of and attitudes toward endangered François' langurs (Trachypithecus francoisi) in a human-modified habitat. Int. J. Primatol., 40: 331-355. https://doi. org/10.1007/s10764-019-00091-0

Niu, K., Xiao, Z., Wang, B., Yang, D., Tan, Chia, L., Zhang, P., Yan, X., Wang, H., Yu, B. and Yang, T., 2016. Population estimates and distribution of françois langurs (Trachypithecus francoisi) in Mayanghe National Nature Reserve, China. J. Zool., https://doi.org/10.13859/j.cjz.201606001

Rodriguez, A., and Delibes, M., 2003. Population fragmentation and extinction in the Iberian lynx. Biol. Conserv., 109: 321-331. https://doi. org/10.1016/S0006-3207(02)00158-1

Schmitt, T. and Seitz, A., 2002. Influence of habitat fragmentation on the genetic structure of Polyommatus coridon (Lepidoptera: Lycaenidae): implications for conservation. Biol. Conserv., 107: 291-297. https://doi.org/10.1016/S00063207(02)00066-6

Trombulak, S.C., and Frissell, C.A., 2000. Review of ecological effects of roads on terrestrial and aquatic communities. Conserv. Boil., 14: 18-30. https://doi. org/10.1046/j.1523-1739.2000.99084.x

Van-Dyke, F.G., Brocke, R.H., Shaw, H.G., Ackerman, B.B., Hemker, T.P. and Lindzey, F.G., 1986. Reactions of mountain lions to logging and human activity. J. Wildl. Manage., pp. 95-102. https://doi. org/10.2307/3801496

Wang, S., Luo, Y. and Cui, G., 2011. Sleeping site selection of Francois's langur (Trachypithecus francoisi) in two habitats in Mayanghe National Nature Reserve, Guizhou, China. Primates, 52: 51- 
60. https://doi.org/10.1007/s10329-010-0218-2

Way, J., 1977. Roadside verges and conservation in Britain: A review. Biol. Conserv., 12: 65-74. https:// doi.org/10.1016/0006-3207(77)90058-1

Zeng, Y., Xu, J., Wang, Y. and Zhou, C., 2013. Habitat association and conservation implications of endangered Francois' langur (Trachypithecus francoisi).PLoS One, pp. 8. https://doi.org/10.1371/ journal.pone.0075661

Zhang, J., Hull, V., Ouyang, Z., Li, R., Connor, T., Yang, H., Zhang, Z., Silet, B., Zhang, H. and Liu, J., 2017. Divergent responses of sympatric species to livestock encroachment at fine spatiotemporal scales. Biol. Conserv., 209: 119-129. https://doi. org/10.1016/j.biocon.2017.02.014

Zhang, W., Tang, Z., Qi, D., Hu, Y. and Hu, J., 2007. Habitat assessment for giant pandas Ailuropoda melanoleuca on the northern slope of the Daxiangling Mountains. Acta Theriol. Sin., 27:146152.

Zhao, C., Yue, B., Ran, J., Moermond, T., Hou, N., Yang, X., and Gu, X., 2017. Relationship between human disturbance and endangered giant panda Ailuropoda melanoleuca habitat use in the Daxiangling Mountains. Oryx, 51: 146-152. https:// doi.org/10.1017/S0030605315000800

Zhao, X., Ren, B., Garber, P.A., Li, X., and Li, M., 2018. Impacts of human activity and climate change on the distribution of snub-nosed monkeys in China during the past 2000 years. Divers. Distrib., 24: $92-$ 102. https://doi.org/10.1111/ddi.12657

Zhou, Q-H., Cai, X-W. and Huang, C-M., 2010. Habitat selection and use of Francois's langurs (Trachypithecus francoisi) in Guangxi Province, Fusui area.

Zhou, Q-H., Huang, Z-H., Wei, H. and Huang, C-M., 2018. Variations in diet composition of sympatric Trachypithecus francoisi and Macaca assamensis in the limestone habitats of Nonggang, China. Zool. Res., 39: 284. https://doi.org/10.24272/j.issn.20958137.2018.046

Zhou, Q., Huang, C., Li, M. and Wei, F., 2011. Ranging behavior of the Francois' langur (Trachypithecus francoisi) in limestone habitats of Nonggang, China. Integr. Zool., 6: 157-164. https://doi. org/10.1111/j.1749-4877.2011.00239.x

Zhu, L., Zhan, X., Meng, T., Zhang, S. and Wei, F., 2010. Landscape features influence gene flow as measured by cost-distance and genetic analyses: A case study for giant pandas in the Daxiangling and Xiaoxiangling Mountains. BMC Genet., 11: 72. https://doi.org/10.1186/1471-2156-11-72

Zhu, L., Zhang, S., Gu, X. and Wei, F., 2011. Significant genetic boundaries and spatial dynamics of giant pandas occupying fragmented habitat across southwest China. Mol. Ecol., 20: 1122-1132. https://doi.org/10.1111/j.1365-294X.2011.04999.x 